\title{
灰 分
}

日本鋼管株式会社 宮。津隆

\section{1 第 1 回協同害験}

\section{1 害験方法 1 )}

(1) 参加分析所……41箇所

(2) 供試標準試粼…20銘柄

（3）分析方法……窒温 $\rightarrow 500^{\circ} \mathrm{C} / 1 \mathrm{hr}, 750^{\circ} \mathrm{C}$ にな つてから $2 \mathrm{hrs}$ 孛標準と专る。 その他は JIS M 8802 そ準ず る。

\section{2 実驗結果 233 ) 4 )}

\section{2 .1 分析装置}

(1) 電気炉

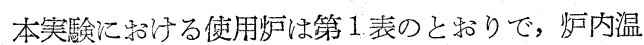

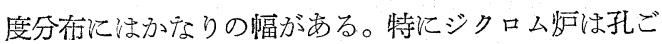
との温度差が大きいから，各孔をランダムに便用した 分析所では $\sigma M$ が大きくなる傾向が認められる。

\section{第 1 表 電気炉方溫度分布}

$$
\begin{aligned}
& \text { 電 気炉台数炉内温度差 } \\
& \text { マッフル於 (ニクロム) } 25 \quad 3 \sim 45^{\circ} \mathrm{C} \\
& \text {, (炭化珪素) } 4 \text { 10 30 }
\end{aligned}
$$

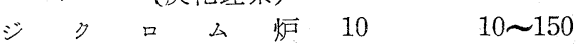

$$
\begin{aligned}
& \text { 計 } 39\left(\begin{array}{l}
\text { 他にガスマッフ } \\
\text { ル将バーナ各 } 1
\end{array}\right)
\end{aligned}
$$

\section{(2) 灰化容器}

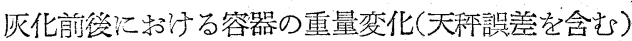
は, 灰分の繰返し誤差に換算して, 通常 $\sigma_{M}=0.01$ $0.03 \%$ ，最高 $\sigma_{M}=0.06 \%$ 程度であつた。

\section{2 .2 許容差汇ついて}

\section{第 2 表 許 容 差}

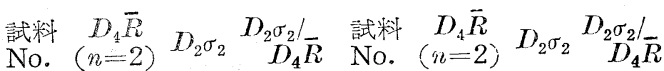

$\begin{array}{llllllll}1 & 0.241 & 0.517 & 2.1 & 11 & 0.203 & 0.454 & 2.2\end{array}$

$\begin{array}{llllllll}2 & 0.219 & 0.280 & 1.3 & 12 & 0.367 & 0.679 & 1.8\end{array}$

$\begin{array}{llllllll}3 & 0.408 & 1.280 & 3.1 & 13 & 0.247 & 0.472 & 1.9\end{array}$

$\begin{array}{llllllll}4 & 0.210 & 0.336 & 1.6 & 14 & 0.269 & 0.900 & 3.3\end{array}$

$\begin{array}{llllllll}5 & 0.236 & 0.384 & 1.6 & 15 & 0.269 & 1.295 & 3.8\end{array}$

$\begin{array}{llllllll}6 & 0.258 & 0.410 & 1.6 & 16 & 0.393 & 1.004 & 2.6\end{array}$

$\begin{array}{llllllll}7 & 0.234 & 0.560 & 2.4 & 17 & 0.286 & 1.059 & 2.9\end{array}$

$\begin{array}{llllllll}8 & 0.357 & 0.734 & 2.1 & 18 & 0.127 & 0.339 & 2.7\end{array}$

$\begin{array}{lllllllll}9 & 0.186 & 0.336 & 1.8 & 19 & 0.212 & 0.461 & 2.2\end{array}$

$\begin{array}{lllllllll}10 & 0.225 & 0.461 & 2.0 & 20 & 0.177 & 0.284 & 1.6\end{array}$

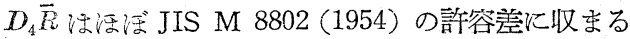
が，異分析所間の 再現誤差管理限度は前者の 2 3 倍
に特よぶ。この值は ASTM (D271-48) の 1.5〜2 倍に 比しかなり大きいので，JIS に異分析所間の許容差を 規定するためには， $\sigma_{b}$ を少くとも現状の $1 / 2$ 以下に下げ る必要がある。

1.2 .3 同一分析所内再現誤差について

(a) $\sigma_{M}$ と分析值の正確度とは関係がない。

（b） $\sigma_{M}$ 之灰分量間には高度の相関がある。

\section{第 1 図 繰返し分析誤差と灰分量の関係}

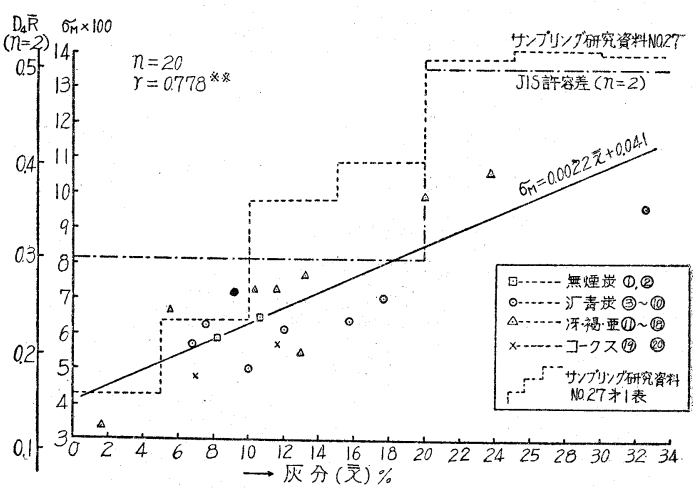

1.2.4 異分析所間再現誤差について

(a) 試料塤間のバラツキは無視し得る。

(b) $\sigma_{b}$ と灰分量間には相関がない。

(c) $\sigma_{b}$ と原炭の $\mathrm{Ca}$ 量間には高度の相関がある。

\section{第 2 図 異分析所間再現誤差亡 $\mathrm{Ca}$ 量の関係}

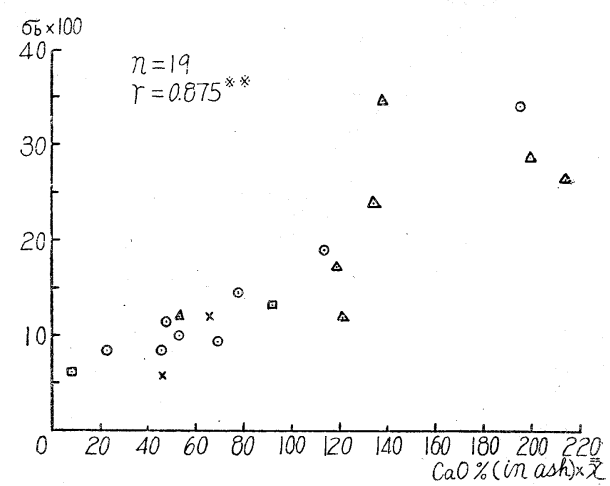

従つて $\sigma_{b}$ は，主として加熱初期に和ける $\mathrm{SO}_{2}, \mathrm{SO}_{3}$ の灰中への固定，㧤よび灰化終期に括村る $\mathrm{CaCO}_{3}$ の 
分解状況に影響されるるのと推定される。

\section{2 .5 その他の情報}

\section{(1) $700 \sim 800^{\circ} \mathrm{C}$ 間の灰化西線4)}

高温連紿精科装置（生研式スプリングパランス）飞 上る灰化曲線を第 3 図江示す。加熱温度を $700^{\circ} \mathrm{C}$ から $800^{\circ} \mathrm{C}$ まで変化させると，鉻柄汇る上るが，いずれる $\mathrm{CaCO}_{3}$ の分解化伴い, 灰分が減少して行く傾向が認め られる。

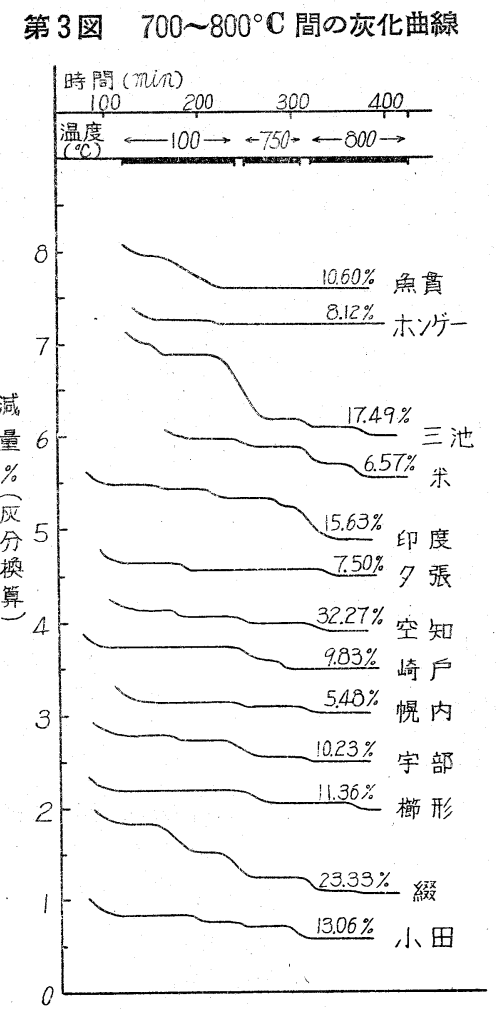

（2）灰の吸湿性についで

試料を $750^{\circ} \mathrm{C}$ で灰化後直に科量ビンに移し, 密柽 して冷却科量し（㚒量約 $1 \mathrm{~g}$ )，その後シリカゲル入り デシケーター中で蓋をとつて一定時間放置後蓋をして 科量, この操作を繰返して各回の增量を求めた結果を 第 4 図に示す。

冷却した灰はデシケーター中でも吸湿し，最初の 10
第 4 図灰の吸湿曲線

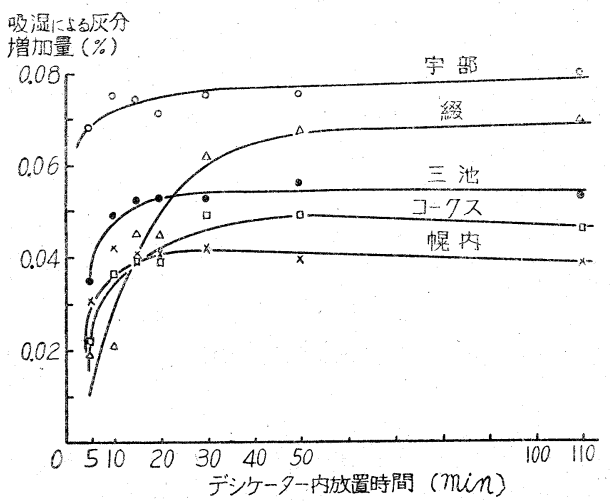

分間にほ医平衡状態に達し，その後の放置時間の長短 には関係なく，灰分分析值として $0.04 \sim 0.08 \%$ 程度の カタヨリを与光ることになる。

(3) コークスの灰化温度についで3

ASTM (D271-48) にはコークスの灰化温度として， $\left\lceil 950^{\circ} \mathrm{C}\right.$ を超えない温度」と規定されている。

9 分析所飞和ける JIS, ASTM の比較実駼結果は次 の通りであつた。

両者の灰分に有意羑が生ずる理由は，第 5 図に示す ように， $950^{\circ} \mathrm{C}$ に加熱したとさ灰中の $\mathrm{CaSO}_{4}$ が分解 （単独では $1,200^{\circ} \mathrm{C}$ 以上にならないと分解しないが， 灰中には $\mathrm{Si}, \mathrm{Al}, \mathrm{Fe}$ などが共存しているため分解温 度は低下活る56) といわ机ている）乙始めているため であらう。な括このため， $950^{\circ} \mathrm{C}$ 灰分の異分析所間再 現精度は $750^{\circ} \mathrm{C}$ の气れよりる不良になつている。

\section{第 5 図 灰中の硫酸塩の分解状況}

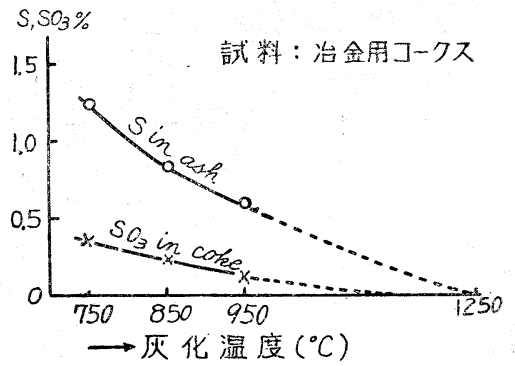

第 3 表

\begin{tabular}{|c|c|c|c|c|c|c|}
\hline 試 & 冶 金 & 用 $=-$ & $\eta x$ & 鋳 物 & 用 $=-$ & $\Rightarrow x$ \\
\hline 9 分析所平均値 & $\begin{array}{c}750^{\circ} \mathrm{C} \text { 灰分 } \\
11.66\end{array}$ & $\begin{array}{c}950^{\circ} \mathrm{C} \text { 灰分 } \\
11.43\end{array}$ & $\begin{array}{c}\text { 偏差 (\%) } \\
0.23\end{array}$ & $\begin{array}{c}750^{\circ} \mathrm{C} \text { 灰分 } \\
7.01\end{array}$ & $\begin{array}{c}950^{\circ} \mathrm{C} \text { 灰分 } \\
6.79\end{array}$ & $\begin{array}{c}\text { 偏差 }(\%) \\
0.22\end{array}$ \\
\hline 差の信 頼 限 界 & \multicolumn{3}{|c|}{$0.311 \geq m \geq 0.153(95 \%)$} & \multicolumn{3}{|c|}{$0.393 \geq m \geq 0.145(95 \%)$} \\
\hline
\end{tabular}




\section{第 4 表 灰化溫度と所間精度の関係}

治金用コークス

$\left.\begin{array}{rrrr} & s . s . & d . f . & \text { m.s. } \\ 750^{\circ} \mathrm{C} \text { 灰分 } & 421 & 8 & 52.62 \\ 950^{\circ} \mathrm{C} \text { 灰分 } & 1233 & 8 & 154.12\end{array}\right\}$

$F_{0}$

2.93

釷物用コークス

$\left.\begin{array}{ccccc} & \text { s.s. } & \text { d.f. } & \text { m.s. } & F_{0} \\ 750^{\circ} \mathrm{C} \text { 灰分 } & 230 & 8 & 28.75 \\ 950^{\circ} \mathrm{C} \text { 灰分 } & 879 & 8 & 109.88\end{array}\right\} \quad 3.82^{*}$

\section{2 第 2 回協同実験}

\section{1 目 標}

以上の結果扰よび多数の資料11 ${ }^{115)}$ から，異分析所 間再現誤差要因の主なるのは,次の二つと考兄られる。

(i ) 灰化初期に和外る硫黄の灰分への固定11) 14) 乃至転移 ${ }^{1115)}$ (加熱速度, 通風度, 同一师その試料装 入数などに支配される)

(ii） $\mathrm{CaCO}_{3}$ の分解の度合5)的（最終加熱温度，時 間隹㝔配される)

したがつて第 2 回実験の目標は次の 2 点に招いた。

（a）加熱速度，通風度を変更して（i）の影響を 確める。

(b) 高温計を較正し, 最終加熱温度を $800^{\circ} \mathrm{C}$ とし て（ii）の影響を消し， $\sigma_{b}$ の低下の度合を求める。

2.2 試 料

$\mathrm{Ca}$ 含有量が高く，かつ前回此較的 $\sigma_{b}$ の大きかつた 4 銘柄およびュークスを選び，いずれも恒湿器に 7 日 間静置後使用した。

\section{3 実験方法?}

\subsection{1 規定条件}

(1) 測温計器 : 参加 8 分析所はそれぞれ使用高温 計および熱電対を資源技術試験所に持らより，標準 訫器と較正すること。

（2）電気炉：マッフル炬を使用し，温度分布を測 定したのち均熱帯だけを使用すること。

(3) 灰化容器 : 種類は問わないが，試料層の厚さ

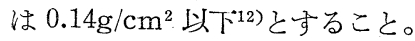

（4）灰の冷却時間：原則として, デシケーター中 で冷えたらすぐ科量すること。

(5) 分析回数：繰返し回数は 2 回とする。たと兄 不完全灰化が明らかであつてる，3回行うことなく そのま報告すること。

2.3.2 因子条件

第 5 表のすべての組合せをとると，1 銘柄とつき 48 と物りとなるので, 各分析所は第 6 表の上5亿策験を 分担した。
第 5 表 因子と水準

\begin{tabular}{|c|c|c|c|c|}
\hline 記号 & 因子 & 水準 1 & 水 淮 2 & 水準 3 \\
\hline$A$ & $\mid$\begin{tabular}{|c} 
灰 \\
化 \\
法
\end{tabular} & $\mid \begin{array}{r}\mid ⿱_{\text {温 } \rightarrow 500^{\circ} \mathrm{C}} \\
1 \text { 時間 } \\
500^{\circ} \mathrm{C} \rightarrow \text { 最終 } \\
\text { 温度 } 1 \text { 時間 } \\
\text { 最終温度保持 } \\
1 \text { 時間 }\end{array}$ & \begin{tabular}{|r|}
||$_{\text {温 }} \rightarrow$ 最 \\
終淐 \\
最終温度 \\
1 保持 \\
時間 \\
再灼熱 1 時間
\end{tabular} & \\
\hline$D$ & 通風度 & 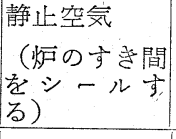 & 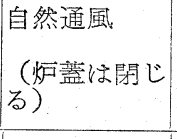 & $\begin{array}{l}\text { 強制通風 } \\
\text { (炉蓋を閜 } \\
2 \mathrm{~cm} \text { 開 } \\
\text { る) } \\
\end{array}$ \\
\hline$F^{r}$ & 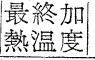 & $750_{-20}^{+10 \circ} \mathrm{C}$ & $800_{-10}^{+20 \circ} \mathrm{C}$ & \\
\hline$P$ & $\mid$ & 1 列に並べ & \begin{tabular}{|l} 
前後 2 列火並 \\
ベる
\end{tabular} & \\
\hline
\end{tabular}

第 6 表 各分析所の分担項目

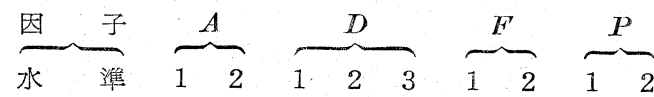

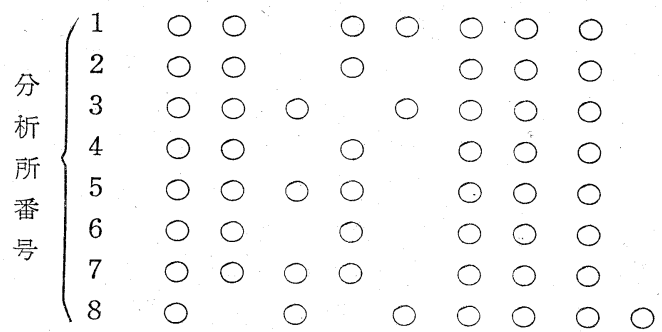

\section{4 実験結果 ${ }^{879) 10}$}

\section{4 .1 分析值の分布状態}

各灰化方法ごとの, 各分析所の分析值の分布状態を 第 6 図淙卞。

\section{4 .2 分散分析結果}

要因 $P$ は有意にはならなからたので省略し，要因 $A$ ， $D, F$ の分散分析結果および各水準平均值の差だけを 第 7 11 表に示す。

\section{5 実駼結果の検討叔上び追加実験}

2.5.1 第 1 回協同実験結果との比較

（1）各灰化方法の比較

第6 园から明らかなように，各灰化方法によつて灰 分平均值も異なるが，分析所閒のバラッキの点からみ れば，むつともすぐれているのは $A_{1} D_{3} F_{1(2)}$ の系列で 西る。これを第12表佂示す。な和 $D_{1}$ の系列は分析所 数が少ないので省略し， $D_{2} ， D_{3}$ をブールして自由度 を大きくした。

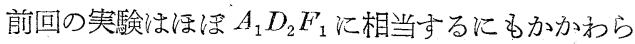
ず，今回の再現䛊差が有意に小さくなつた理由は，高 温計の較正, 炉内均熱带の使用, 昇温速度の厳守など によるものであうう。 
第 6 図 $\bar{x}$ の分布 状態

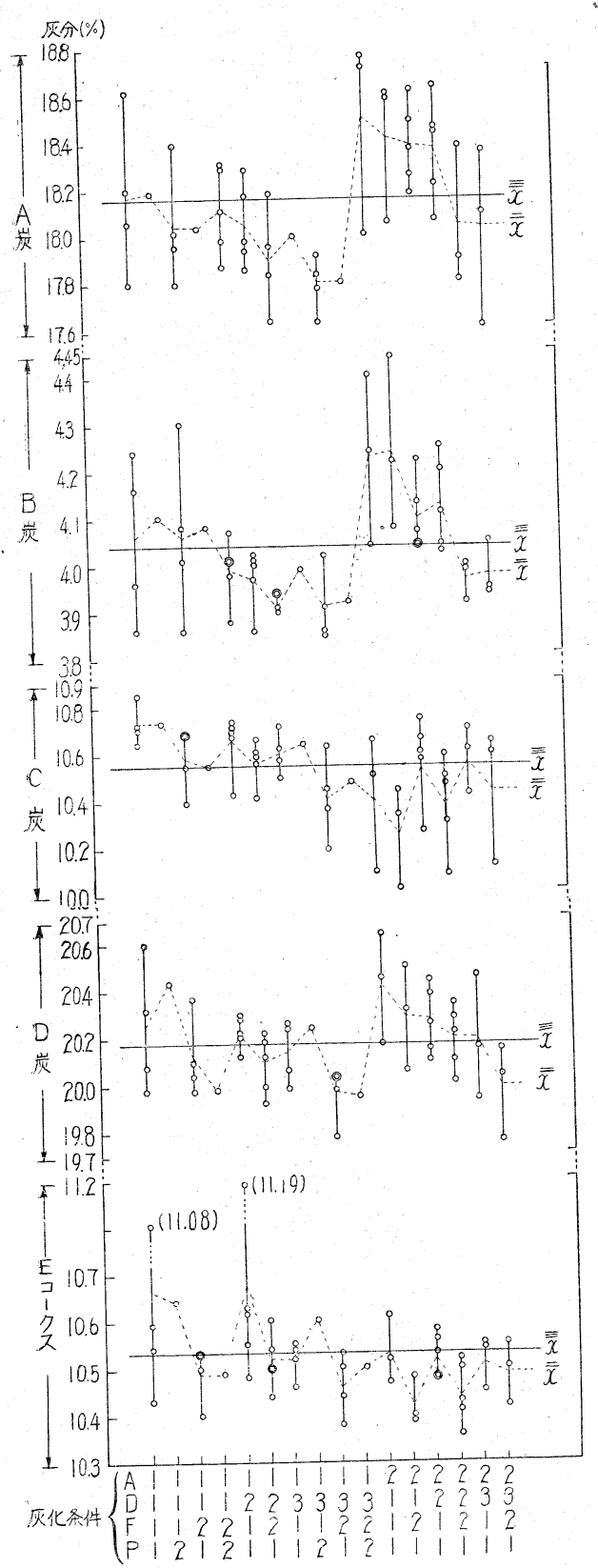

第 7〜 11 表

\begin{tabular}{|c|c|c|c|c|c|c|c|c|}
\hline 产 & 7 & & & & & & & \\
\hline 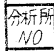 & 総平均 & 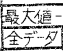 & 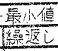 & $\frac{1}{14}$ & & $\frac{5}{12}$ & 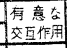 & 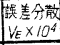 \\
\hline 1 & 18.124 & 0.81 & 0.28 & 62 & & 6044 & & 681.9 \\
\hline 2 & 18.168 & 0.38 & 0.16 & 600 & & 0.1352 & $A F^{*}$ & 52.9 \\
\hline 3 & 18.402 & 1.15 & 0.68 & 6252 & 186 & 10,160 & & 406.2 \\
\hline 4 & 18.096 & 0.50 & 0.34 & 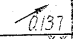 & & $00>-$ & & 337.1 \\
\hline 5 & 18.304 & 0.87 & 0.22 & 1068 & & 10078 & & 430 \\
\hline 6 & 18.351 & 053 & 0.46 & o.18 & & $\widehat{T 030}$ & & 522.1 \\
\hline 7 & 177799 & 0.43 & 0.19 & 0,604 & & 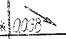 & & 55.9 \\
\hline 8 & 18,008 & 0.62 & 0.33 & & 24 & $\operatorname{lig}_{x}$ & & 2008 \\
\hline & 8 & & $E$ & & & 崖一 & & \\
\hline 1 & 4.026 & 0.45 & 0.26 & A & & 6053 & & 79.1 \\
\hline 2 & 4040 & 0.18 & 0.08 & 610 & & $\overrightarrow{0}$ & & 13.2 \\
\hline 3 & 4.144 & 0.78 & 0.24 & & & 6032 & & 81.2 \\
\hline 4 & 4.044 & 0.29 & 0.29 & 0 & & $60022^{\circ}$ & & 170.9 \\
\hline 5 & 4051 & 0.53 & 0.19 & 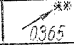 & 60006 & 0000 & & 78.6 \\
\hline 6 & 4.024 & 0.06 & 0.05 & $\widehat{0002}$ & & 6000 & & 2.6 \\
\hline 7 & 3.974 & 0.28 & 0.11 & & $10 \times$ & $\log ^{\circ}$ & $D F^{*}$ & $\begin{array}{l}x_{1} \\
\end{array}$ \\
\hline 8 & 4046 & 0.41 & 0.13 & & & $60044^{\circ}$ & |DFP & x. 27.9 \\
\hline & 9 & & & & & 崖 & & \\
\hline 1 & 10.594 & 0.45 & 0.25 & 6.040 & 0.016 & 6003 & $A D^{*}$ & 746 \\
\hline 2 & 10.555 & 0.48 & 0.10 & 0070 & & $(0,390 \times$ & & 17.0 \\
\hline 3 & 10.671 & 0.51 & 0.12 & $0.137=$ & 6021 & $63\rangle^{2}$ & $A D^{*}$ & 812 \\
\hline 4. & 10.628 & \begin{tabular}{|l|}
0.30 \\
\end{tabular} & 0.20 & $60055^{\circ}$ & & 10002 & & 668 \\
\hline 5 & 10.398 & 0.83 & 0.33 & $0.5606 \times$ & 6021 & lone & & 1818 \\
\hline 6 & 10.615 & 0.28 & 0.03 & $1.40 \times *$ & & $0114 \times$ & $A F^{*}$ & 2.2 \\
\hline 7 & 10.407 & 0.68 & 0.15 & ilit $: *$ & $0.184 \times * *$ & $10288^{2} \times * \times$ & & 25.5 \\
\hline$B$ & 10.601 & 0.34 & 0.14 & & $60057-$ & $\log _{4}+3$ & & 43.8 \\
\hline & 10 & & & & & 崖 & & \\
\hline 1 & 20194 & 0.59 & 0.29 & $60000^{2}$ & $3 T^{\circ}$ & orido & $A F D^{*}$ & 512 \\
\hline 2 & 20.092 & 0.36 & 0.12 & 6065 & & $\log _{1320}$ & & 34.5 \\
\hline 3 & 20.336 & 0.79 & 0.24 & 0.204 & & $0,7 \times k:$ & $D F^{*}$ & 1062 \\
\hline 4 & 20.112 & 0.30 & 0.25 & $0.120^{\circ}$ & & $10000^{\circ}$ & & \begin{tabular}{|l}
106.2 \\
\end{tabular} \\
\hline 5 & 20.208 & 0.60 & 0.24 & 0.327 & 6003 & $10135 \times$ & & 5399 \\
\hline 6 & 20279 & 0.40 & 0.34 & 6047 & & wot & & 1859 \\
\hline 7 & 199605 & 0.51 & 0.16 & 6038 & & $1000 \times x$ & $05^{*}$ & 29.1 \\
\hline 8 & 20.199 & 0.81 & 0.33 & & $10,103 x$ & hescos & & 178.7 \\
\hline & 11 & & 5 & & $\exists-7$ & 즈 & & \\
\hline 1 & 10.529 & 0.35 & 0.19 & $6 / 18$ & $z$ & 1930 & $\mid \begin{array}{l}A D \\
A F D\end{array}$ & 48.5 \\
\hline 2 & 10.545 & 0.25 & 0.06 & 60000 & & 1020 & & 10.7 \\
\hline 3 & 10.518 & 0.62 & 0.62 & 0.032 & 6012 & 60014 & & 2500 \\
\hline 4 & 10.512 & 0.16 & 0.06 & To055 & & $\log _{0} x$ & & 53 \\
\hline 5 & 10.633 & 0.95 & 0.16 & $0.035^{2} \times x$ & 0.005 & $103578 \times 2 \times$ & $A F^{*}$ & 46.5 \\
\hline 6 & 10.504 & 0.25 & 0.10 & $0.117 \%$ & & $\log _{2} \times$ & & 156 \\
\hline 7 & 10.440 & 0.19 & 009 & 0.012 & $10020 \mathrm{~m}$ & $100808 \times$ & & 122 \\
\hline 8 & 10545 & 0.25 & 0.12 & & $10026=$ & 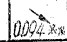 & & 15.8 \\
\hline
\end{tabular}


第 12 表 分析所間のバラッキの比較 (灰化方法别) $\left(\mathbf{V} \times 10^{4}\right)$

\begin{tabular}{|c|c|c|c|c|c|c|c|c|c|c|c|c|c|}
\hline 方 & 法 & & 可の实験 & $\left(A_{1} D_{2}\right)$ & & $A_{2} D_{2}$ & ${ }_{(3)} F_{1}^{\prime}$ & $A_{2} D_{2}$ & (3) $F_{2}^{\prime}$ & $A_{1} D$ & (3) $F_{1}^{\prime}$ & $A_{1} D_{2}$ & 3) $F_{2}$ \\
\hline 分 & 散 & $\begin{array}{c}V_{1} \\
(n=41)\end{array}$ & $\frac{V_{1}}{V_{121}}$ & $\begin{array}{c}V_{2}^{(1)} \\
(n=8)\end{array}$ & $\frac{V_{1}}{V_{121}}$ & $\begin{array}{l}\text { 平均值 } \\
(n=7)\end{array}$ & $V_{221}$ & $\begin{array}{l}\text { 平均值 } \\
(n=7)\end{array}$ & $V_{222}$ & $\begin{array}{l}\text { 平均値 } \\
(n=8)\end{array}$ & $V_{121}$ & $\begin{array}{l}\text { 平均值 } \\
(n=8)\end{array}$ & $V_{122}$ \\
\hline A & 楚 & 1204.1 & 2.35 & 692.6 & 1.37 & 18.35 & 958.8 & 18.21 & 1055.4 & 18.05 & 512.1 & 17.91 & 250.6 \\
\hline B & 炭 & 163.8 & $4.16^{*}$ & 214.0 & $5.43^{*}$ & 4.04 & 102.0 & 4.06 & 110.4 & 3.96 & 39.4 & 3.94 & 55.7 \\
\hline $\mathrm{C}$ & 若 & 595.4 & $8.11^{* *}$ & 204.0 & 2.79 & 10.56 & 286.6 & 10.39 & 519.9 & 10.68 & 73.3 & 10.49 & 179.7 \\
\hline $\mathrm{D}$ & 炭 & 739.8 & $6.64 * *$ & 152.7 & 1.37 & 20.23 & 386.5 & 20.08 & 230.8 & 20.17 & 111.4 & 20.01 & 171.9 \\
\hline & & 155.5 & $(4 . \overline{57} *)(2)$ & 124.4 & $(3.6 \overline{6})^{(2)}$ & 10.52 & 20.3 & 10.46 & 41.6 & 10.63 & $\begin{array}{l}531.8 \\
(34.0)^{(2)}\end{array}$ & 10.47 & 30.2 \\
\hline
\end{tabular}

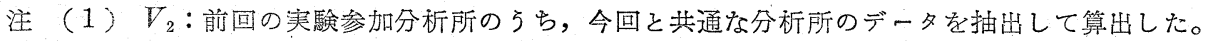

（2）明らかに不完全灰化と考えられるデータ1個を除いた場合。

(2) 許容因

\section{第 13 表 鼓 容 差}

前回の実 験 今回の実験 (8 分析所)

銘 柄 $\overbrace{\begin{array}{c}D_{4} \bar{R} \\ (n=2)\end{array} D_{2} \sigma_{2} \frac{D_{2} \sigma_{2}}{D \bar{R}_{4}}}^{\text {(41分析所) }} \overbrace{\begin{array}{c}D_{4} \bar{R} \\ (n=2)\end{array} A_{1} D_{2(3)} F_{2} \frac{D_{2} \sigma_{2}}{D_{2} \sigma_{2}}}^{\frac{D_{2} \bar{R}}{D_{4}}}$

$\begin{array}{llllllll}\text { A } & \text { 崖 } & 0.408 & 1.280 & 3.1 & 0.510 & 0.582 & 1.1\end{array}$

$\begin{array}{llllllll}\mathrm{B} & \text { 炭 } & 0.247 & 0.472 & 1.9 & 0.237 & 0.276 & 1.2\end{array}$

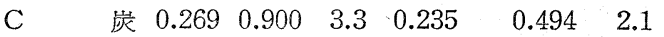

D $\quad \begin{array}{lllllll}\text { 炭 } & 0.393 & 1.004 & 2.6 & 0.348 & 0.483 & 1.4\end{array}$

$\begin{array}{llllllll}\mathrm{E} \text { コークス } & 0.212 & 0.461 & 2.2 & 0.200 & 0.203 & 1.0\end{array}$

前回に比較して $D_{4} \bar{R}$ は大差ないが， $D_{2} \sigma_{2}$ は約 $/ 2$ と なりほぼ所期の目的を達した。両者の比も著しく小さ くなり，ASTM と同水集になつたので，今後 JIS に 異分析所間の許容差を規定することは可能であろう。

2.5 .3 分析誤差要因の検討

(1) 補正灰分の算出

第 7〜11表に示すように，要因 $A ， D ， F$ はそれぞ れ有意となる埸合が多く（水準間の傾向は，銘柄によ り一様ではないが）かつ分析所間の傾向もほぼ一致し ているので，これらが異分析所間の誤差要因の大部分 を占めるものと推定される。

要因 $A, I$ は硫黄の灰中への固定量

" $F$ は $\mathrm{CaCO}_{3}$ の分解の度合

第 14 表

\begin{tabular}{|c|c|c|c|c|c|c|c|c|}
\hline \multirow{2}{*}{ 铅婳 } & \multirow{2}{*}{$\begin{array}{l}\text { 総平均 } \\
S \%\end{array}$} & \multirow{2}{*}{\multicolumn{2}{|c|}{ 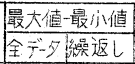 }} & A & 0 & $F$ & \multirow{2}{*}{$\begin{array}{l}\text { 有意な } \\
\text { 交互作周 }\end{array}$} & \multirow{2}{*}{ 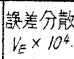 } \\
\hline & & & & 12 & 13 & 2 & & \\
\hline A 岸 & $\begin{array}{c}3.368 \\
(1.557)\end{array}$ & 1.68 & 0.68 & $\begin{array}{l}0.690 \\
(0340)\end{array}$ & $\begin{array}{l}0.565 .5 * * \\
(0.2977)\end{array}$ & $\begin{array}{l}0.147 \\
(0.080)\end{array}$ & & 550 \\
\hline B岸 & $\begin{array}{c}4.468 \\
(0.463) \\
\end{array}$ & 3.88 & & $\begin{array}{l}* * \\
0.985 \\
(0.120)\end{array}$ & $\begin{array}{c}2.480 \\
(0.297)\end{array}$ & $\begin{array}{l}* * \\
0.495 \\
(0.054)\end{array}$ & & 378 \\
\hline C炭 & $\begin{array}{l}5.467 \\
(1.460) \\
\end{array}$ & 1.34 & 0.40 & $\begin{array}{l}0.324 \\
(0.104)\end{array} * *$ & $\begin{array}{l}0.056 \\
(0.012)\end{array}$ & $\begin{array}{l}0.438 \times) \\
(0.136) *\end{array}$ & $A \cdot D^{*}$ & 640 \\
\hline D炭 & $\begin{array}{c}3.283 \\
(1.668) \\
\end{array}$ & 193 & 0.38 & $\begin{array}{r}C^{* * *} \\
0.494 \\
(0.268) \\
\end{array}$ & $\begin{array}{l}0.406 * * \\
(0.220)^{*}\end{array}$ & $\begin{array}{l} \\
0.056 \\
(0.020)\end{array}$ & $D F^{*}$ & 256 \\
\hline $\begin{array}{c}E \\
-7 x \\
\end{array}$ & $\begin{array}{l}1.586 \\
(0.417) \\
\end{array}$ & 0.30 & 0.25 & $\begin{array}{l}0.019 \\
(0.005)\end{array}$ & $\begin{array}{l}0.11 \\
0.004)\end{array}$ & $\begin{array}{l}0.079 \\
(0.022)\end{array}$ & & 101 \\
\hline
\end{tabular}

(注)( )内淙炭に效する $\mathrm{SC}_{3} \%$
をそれぞれ交配するものと考光られるので，筆者等は 本実験中に得られたすべての灰について灰中の硫贵を 定量し(第 14 表)，乙れを原炭に対する $\mathrm{SO}_{3}$ 量深換算 して，それぞれの灰分から差引美，補正灰分を求めて みた。

これを第7〜10困に示す。

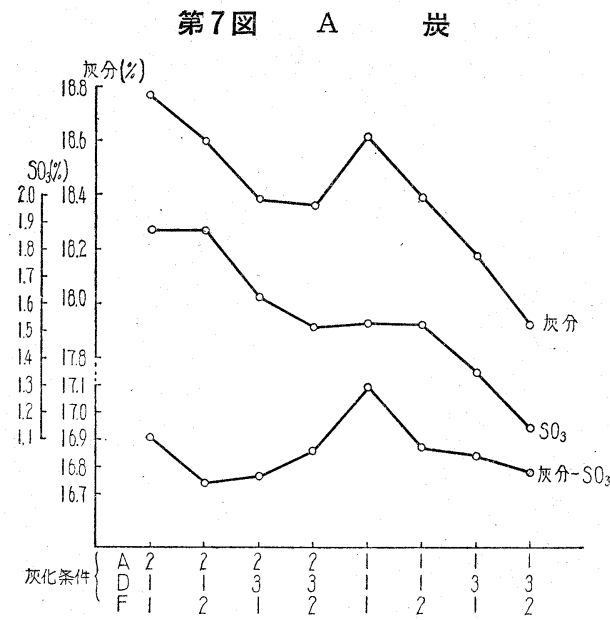

第8図 B 孷

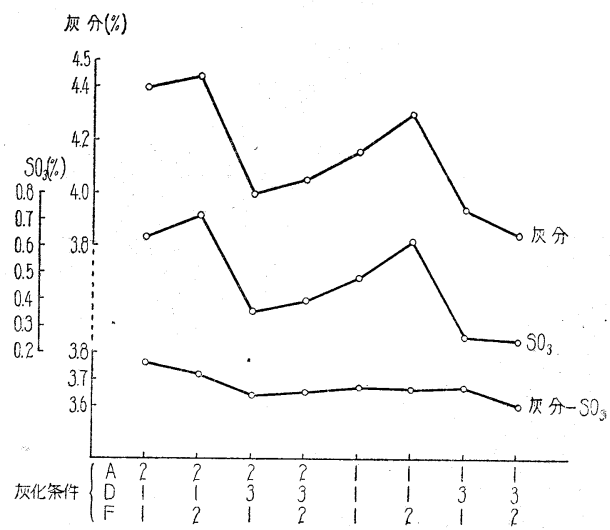


第9図 C 崖

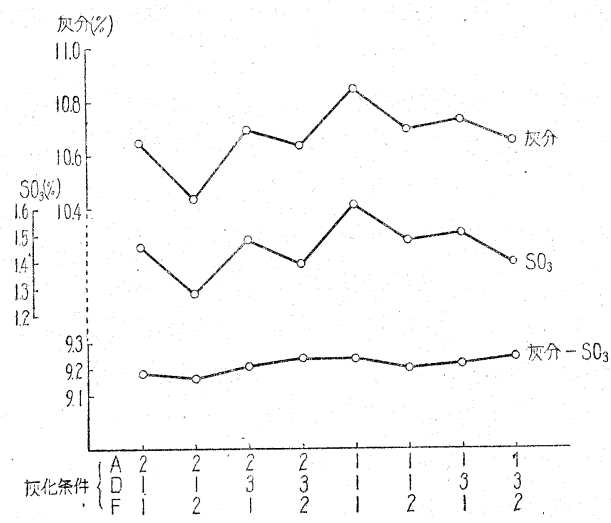

第10図 D 崖

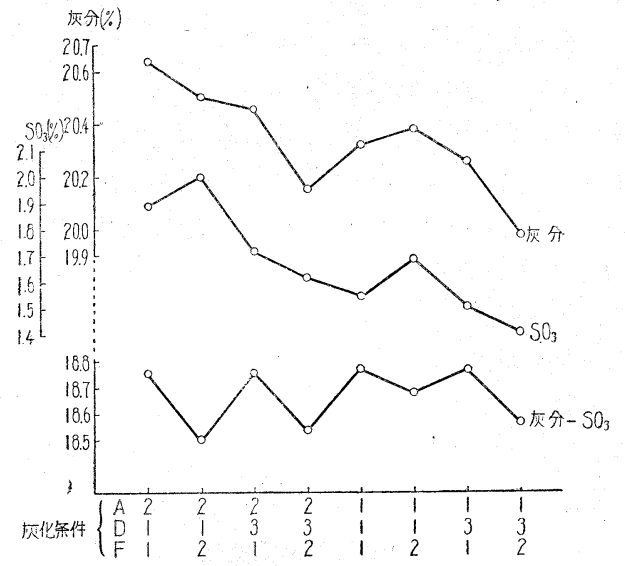

(2) 考察

(a) A 岩, B崖

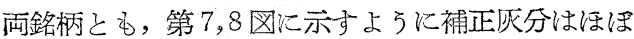
一定となり，有意であつた要因 $A, D$ の影響が消える。 すなわち要因 $A$ ，Dの各水準に淤る灰分の差は，灰 中に固定された硫酸塩の量の差によるものである。

(b) C 炭

第 9 図に示导ように，やはり補正灰分が活ぼ一定と なるから，灰中の硫酸湓の量により灰分が変化する点

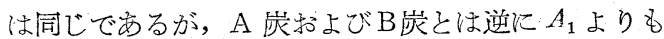
$\mathrm{A}_{2}$ の灰分方有意儿低い。これは灰中に固定される琉 酸塩の絶対量の閒題ではなく，硫酸塩の分解によるも のと考兄られる。徒来，灭中の $\mathrm{CaSO}_{4}$ は，少なくと も $850^{\circ} \mathrm{C}$ 以上飞ならないと分解しない(5)6)といわれて いたが，第14 表から明らかなように，C炭の圧中の硫 酸塩はきうめて分解しゃすく，750〜 $800^{\circ} \mathrm{C}$ 間ですで に分解し始める。従つて, $F_{1}$ よりも $F_{2}$ の灰分が低く なり, また加熱最高温度に保持される時間の長い $A_{2}$
の灰分が $A_{1}$ よりも低くなるものと推定される。灰分 とは，炭酸塩が完全に分解し，硫酸塩が分解し始めない

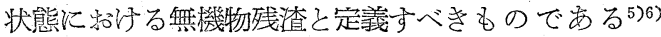
から，C宸に関する限り，灰化温度は $750^{\circ} \mathrm{C}$ を越えて はならず，かつ高温度に長時閒放置すべきではない。

(c) D 宸

第10目に示すように，補正灰分には， $F_{1}$ と $F_{2}$ の 差がはつきり現われて，要因 $A, D$ の影響が消学る。

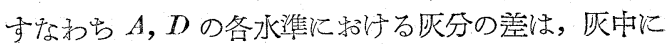
固定された硫酸塩の量の差によるるのであり， $F_{1}, F_{2}$ の灰分の差は，炭酸塩の分解によるものと推定され る。従つて D 炭の灭化温度は $750^{\circ} \mathrm{C}$ では不充分で， 少なくとも $800^{\circ} \mathrm{C}$ は必要であらう。

(d) コークス

コークスの灰分の変動は灰中の硫酸睢の量とは関係 がない。要因 $A, F$ が要因となつた分析所が多いが， これは炭素の不完全灰化によるものであろう。通常の 石宸ならば $A_{1} D_{2} F_{1}$ のの条件で完全に灰化するが，コ 一クスの場合には兏化中攪汼しない限り，灰中に未灰 化の孷素粒子が認められる場合が多い。従つて完全灰 化の条件としては少なくとも $800^{\circ} \mathrm{C} 2$ 時間以上加熱が 必要と考えられる。

\subsection{3 灭化時に和ける硫黄および炭酸塩の挙動}

以上の実験結果から, 硫黄の灰中への固定量の差異 が異分析所間の再現誤差に大きく影響することが判つ. た。分析所No. 3 ではその機構を明らかにするため に, $\mathrm{A}$ 炭について $A_{1} D_{2} F_{2}$ の扊化方法により各 $100^{\circ} \mathrm{C}$ ごとに加熱残渣を作製し，その扝の扝のについて全硫

\section{第11図 可化時における硫黄および炭酸笽の挙動}

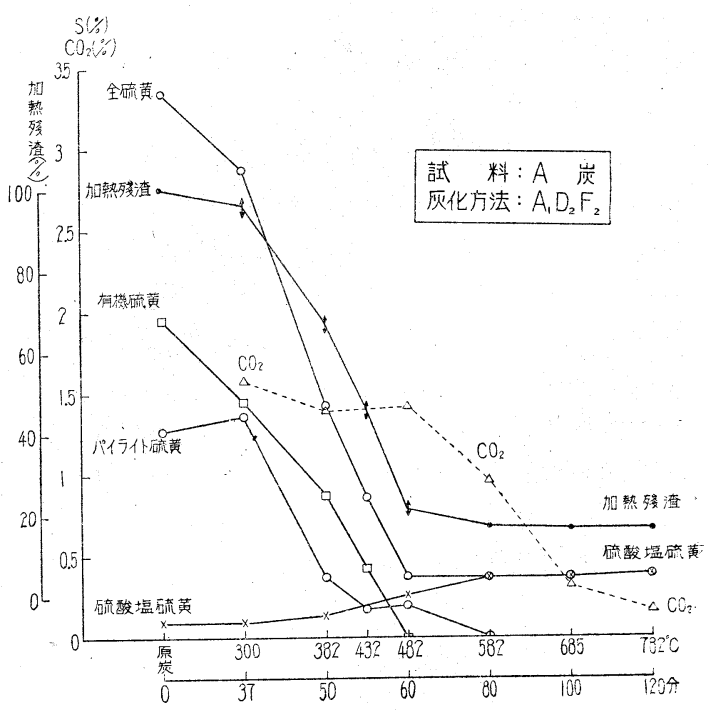


黄, 硫酸塩硫黄, パイライト硫黄および炭酸塩をとれ ぞれ定量し，その変化状況を追跡した。実験結果を第 11図汇示す。

$A_{1} D_{2}$ の条件では $500^{\circ} \mathrm{C}$ まで有機硫黄の全部, パ イライト硫黄の大部分が燃焼揮散するので, $\mathrm{CaCO}_{3}$ の

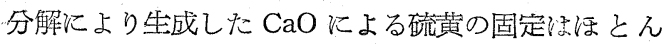
ぞ生じないから，硫酸塩の増加量は比較的少ない。乙 か乙如何に灰化条件を厳密涀定してる $\mathrm{CaCO}_{3}$ の分 解以前江灰中に存在する $\mathrm{CaO}$ のため汸, 原炭の硫酸 塩量がある程度増加することは避けられない。

一方協同実験結果比抒いて， $A_{2}$ 就よび $D_{1}$ の灰分が 高かつたのは, 有機硫黄, パイライト硫黄が燃焼し終 らない5ちに $\mathrm{CaCO}_{3}$ が分解し始如, 生成した $\mathrm{CaO}$ に よつて多量の $\mathrm{SO}_{2}, \mathrm{SO}_{3}$ が灰中に $\mathrm{CaSO}_{4}$ として固定 されたためと考宎られる。

\section{3 第 1 回, 第 2 回協同実験結果の総括}

以上の実験結果から次の事項が明らかになつた。

(1) 高温計の較正, 歺内均熱带の便用, 室温から $500^{\circ} \mathrm{C}$ まで 1 時間かけて昇温, 通風量の增大などの灰 化条件を守ることによつて，異分析所間の再現誤差は 第 1 回協同実験の 約 $1 / 2$, 同一分析所内繰返し 誤差の 1.0〜2.1 倍程度となつた。

(2) 異分析所間の再現誤差は, 主として次の 3 要 因のバラッキによるるのと推定される。

(a) 加熱初期の昇温速度 $\ldots$... 灰中に固定される硫

（b）炉内通風度\}酸塩量を支配する。

(c) 最終加熱温度……炭酸湓 (時には硫酸塩も含 まれる）の分解状沉を支配する。

従来, 異分析所間の再現愦差が同一所内のそれ飞比 ベてかなり大きからたのは，JIS を初め各国の現行覞 格にこれらの操作について明確な規定がなかつたた めであるう。

（3） $\mathrm{A}$ 炭の場合, 自然通風状態で $500^{\circ} \mathrm{C}$ 禾で 1 時 間か子て昇温すると, $\mathrm{CaCO}_{3}$ の分解以前に有機硫黄の 全部, パイライト硫黄の大部分が燃焼揮散する。しか 乙 $\mathrm{CaCO}_{3}$ の分解以前に灰中に $\mathrm{CaO}$ が存在与るとき は, 通風をき放めてよくしない限り, 方る程度の硫酸 塩の固定はさけられない。

$\mathrm{CaCO}_{3}$ は $500^{\circ} \mathrm{C}$ から分解し始め, $750^{\circ} \mathrm{C}$ 付近木で

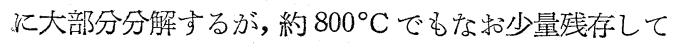
いる。

（4）“灰分”とは次のように定義すべきものであ ちら。

「“灰分”とは，有機硫黄怙よびパイライト硫黄の然 焼により生成する $\mathrm{SO}_{2}, \mathrm{SO}_{3}$ の灰中固定される量が
最少になるように加熱し,かつ炭酸塩が完全に分解し， 硫酸笽の分解が開始しない状態に和ける無機物残渣を いら。」

一般にこの定義を゙満足させるには，炉内へ多数の試 料（特汇高䟽黄分崖が危険）を同時洷大寸ることを 避けるとともに，500 $\mathrm{C}$ 禾で少なくとも1時間かけて ゆるやかに界温し，炬内通風量を增大すればよいので あるが，最適最終加熱温度は鉻柄汇上り異なる (A，D 炭は少なくとも $800^{\circ} \mathrm{C}$ を必要とするが，C炭は $750^{\circ} \mathrm{C}$ を超兊てはいけない）ので，規格温度としては，なる べく多数の銘唡们つ笑験家行つて，最大公約数的炕 求めるか, あるいはランク別に温度をかえるかしなけ ればならないであるう。

[付記] 国際標集化機棈・固体燃料部会

（ISO/TC 27）との関連

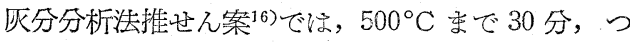
いで $815^{\circ} \mathrm{C}$ まで 30〜60 分かけて昇温し，恒量认なる まで $815 \pm 10^{\circ} \mathrm{C}$ 保存する方法 $\left(A_{2} D_{3} F_{2}\right.$ 代相当する $)$ を採用している。炉内通風量をきわめて大きく、すな わち, 师内容積 $\times 4\left(\mathrm{~cm}^{3} / \mathrm{sec}\right)$ と規定しているので, $A_{2}$ でもよいのである万が，日本では，そのような炉 は汪とんど使われていないので，現段階としては $A_{1}$ を 採用すべきであうう。

なお，日本でる将来は，マッブル怇後部には，熱電 対孔以外飞大きな排気煙筒をつけて，通風量を増大す る方向に向うべきであろう。

\section{4 第 3 回協同実験 ${ }^{17)}$}

前 2 回の協同実験により, 非常に多くの情報が得ら れたが, 最終加爇温度に関しては, 国内孷に対して $750^{\circ} \mathrm{C}, 800^{\circ} \mathrm{C}$ のいずれを光らぶべきかを決定するこ とができなかつたので,第 3 回協同実験が計画された。 本実験の目的は次のと扔りである。

(1) 異分析所間許容差の決定

（2）第 2 回協同実験に和いて, 所間再現誤差の低 下に有効でめつた次の諸操作の再確認

(i) 高温計の較正

(ii） 灰化览内均熱带の夕の便用

（iii）加熱初期の舁温速度をゆるやかとすること

（iv）炬内通風量の増大

（3）最終加熱温度を $750^{\circ} \mathrm{C}, 800^{\circ} \mathrm{C}$ のいずれにす べきかの決定

（4）天秤誤差と分析操作の誤差を分離するため, 天秤の再現精度に関する情報を得ること。

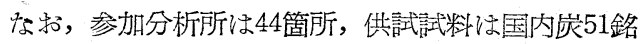
柇, データ総数は 3564 で, 現在実験結果の集計, 解 
析中である。

\section{交献}

1）日科技連・サンプリング研究会：SC-Instruction -4 (1954).

2) 日科技達・サンプリング研究会：サンプリング研 究資料 No. 57 SC-150 (1954).

3）今泉, 寺元, 宮津, 森田, 似鳥, 藤森: 品質管理 5. (1954) 742.

4）佐藤，宮津，渡辺：日本鋼管技報 No. 3 (1955) 190.

5) 宗宮, 平野：工化 42 (1939) 45.

6) H. Moureu R. Sabourin: ISO/TOO 27-140F (1953)

7）日科技連・サンプリング研究会：SC-Instruction 8- (1955).

8) 日科技連・サンプリング研究会：サンプリング研 究資料 No. 91 SC-255 (1956).
9）石川, 寺元, 宮津, 似鳥：品質管理 6 (1955) 107 。

10）宮津，笠原，渡辺：日本鋼管技報 No. 6 (1956) 182.

11) Fixation of Sulphur in Coal Ash and its Influence on Ash Determination, ISO/TO27-47E (1951)

12) Report of 2nd Meeting, ISO/TO27-116E (1952)

13) Report of 3rd Meeting, ISO/TO27-205E (1953)

14) Report of 1st Meeting of Working Group 2, ISO/TO27-231E (1955)

15) B. S.No. 1016-1942, 31.

16) Draft ISO Recommendation No. 170 , Determination of ash in Hard Coal, ISO/TO27-329E (1957)

17）日科技連・サンプリング研究会：SC-Instruction: 12 (1956).

\section{揮発分}

\section{三菱鉱業株式会社 石井裕德}

\section{I 要旨}

昭和29年 4 月〜 7月に実施した標準試料配布による 分析誤差検討第 1 回協同実験結果を解析検討した結果 によれば，通常法（急熱法）に和いてその分析所間の バラツキ $\sigma_{c}$ は大略 ISO (Internation Organization for Standardization) 資料の約 2 倍であつた。

特殊な銘柄のものすなわち揮発分の過大なるの或い は飛散し易いものたと党ば亜炭, 褐炭, 米国炭, 三池 孷などに晾いては異常なバラッキを示していた。

第 2 回の共同実騟に当つては第 1 回の実駼結果より 誤差要因と考光られるものを拔き出し，特殊な鉻柄は 一応除外して歷青炭々ついて次の要因をとつて実験計 画を行つた。目標としては $\sigma_{b}$ をISO 資料の程度に小 さくすることを主眼とした。

要因
A) 炉
B）炉内の雾国気
C) 調整温度
D) 操 作

各要因汇影いて 2 乃至 3 水準を定め, かつ規準法と 任意に選択するものとに分類した。

\section{II 計 画}

(1) 試 料 a) 岸 種

特殊な銘柄については一応除外し瀝青炭にして飛散 なぞの甚だしくないるのを加熱減量で20〜50\%の範囲 で選んだ。但し，D炭のみは前回どの比較の意味もあ つて附加することにした。

b ) 試料の恒湿状態

7 日間以上恒湿器中に放置したものを使用した。

(2) 実験装置

a) 炉

1）緃型管状電気师で寸法は $\phi 40 \sim 55 \mathrm{~mm}$, 高さ 150 〜200 mmのものを使用することとした。(基準法) 炉内の温度分布は通常の炬に㨟いては前回の実験 同様に白金坩佩装大位置を中心として高低 5 力所 （白金坩堝装大位置の中心点，蓋の真上の点，蓋の 上方 $1 \mathrm{~cm}$ の点, 底の真下の点, 底の下方 $1 \mathrm{~cm}$ の点) を測定する。

2) 特殊な师（たとえば1回に 4 コの試料を同時に 測定する炉など）に和いては坦堝装入位置の前後左 右の温度も記入することにした。（任意）

b ) 高温計

便用する高温計は熱霞対と組合わせて資源技術試験 所持参し一括較正を行つだ。 な特泠接点容器には氷を入れて便用した。 